UDC 378.147:004.75

O. Poliak, PhD (Pedagogical Sciences), Assoc. Prof.

Taras Shevchenko National University of Kyiv, Kyiv, Ukraine

\title{
MODERN INFORMATION MOBILE TOOLS OF TRAINING IN HIGHER EDUCATION INSTITUTIONS
}

\begin{abstract}
The article is devoted to modern information tools of training as a way to optimize the process of training future specialists. Emphasis is placed on the importance of technological innovation and the theory of learning in the application of a variety of technologies to teaching and teaching.

It is determined that the patterns of behavior of modern students are changing with respect to their rapidly expanding digital environment. Modern digital students think and process information differently from their predecessors - thinking in parallel and linear models and reading visual images that could be used to read text.

It is emphasized that new technologies, such as those described in the article, can give students of the information society and the interaction society the opportunity to receive increased and continuous participation in learning.

Active students interact with their environment and manipulate objects in that environment, observe the impact of their interventions, and build their own interpretations of the phenomena and results of manipulations, share these interpretations with others. These descriptions offer connections to previously identified features of the Information Society and the Society for Interaction and New Technologies.

Different approaches of providing modern active education in higher education institutions are analyzed. In summary, mobile learning devices can provide individuality through unique profiles, this category of technology can be a proper choice of learning environment aimed at enhancing individual learning orientation. Mobile devices need to be in tune with how events are happening around the world and the web, even if those devices have been used for personal purposes only. It is emphasized that a critical aspect of such a strategy is that the mobile device is not simply integrated into the educational and higher education institutions or fell into the hands of its user, as has been done, for example, with recent initiatives on computers and laptops. On the contrary, individual profiles must be intentionally designed into the device and involved in the educational process in educational institutions in general and in higher education institutions in particular.

Keywords: mobile information technology, mobile devices, e-learning, mobile learning, blended learning, active training.
\end{abstract}

Formulation of the problem. The use of various technologies for teaching and teaching depends on two significant forces: the field of technological innovation (especially today, in hardware and software) and the field of theory of learning. In terms of technological trajectory, training has evolved from textbooks to television, computers, and now to mobile digital devices in a relatively short time. In terms of theoretical trajectory, extensions in ontological and epistemological thought provoked a transformation of educational paradigms (such as behaviorism, cognitivism, and constructivism), which implied a movement toward a more self-regulating, contextual, and interested approach. The development of ways of knowing and ways of learning were shaped by the evolution of society from the industrial and information periods to the age of interaction.

Often, technology and theory of learning evolve along two separate trajectories within less socially complex "labs" or "minds". However, experience indicates that they should be closely linked in practice. That is, when new technologies are introduced, researchers try to apply these technologies to educational purposes, often hoping to demonstrate, through empirical evidence, a better quality of education. Teaching staff (teachers, instructors, etc.), given the real needs of students and the difficulties faced by the educational context, seek to apply adequate educational theories and teaching approaches to integrate new technologies as they enter the information age stage, and the main focus is on delivering and accessing fast, sufficient and complex information. Actual tasks for scholars and practitioners exploring these issues are to use new technologies as a means to improve learning rather than as an end in itself, ie to adopt a pedagogically disciplined approach to teaching and learning to innovate.

Research objective is to analyze information mobile technologies in the organization of active learning in higher education institutions and to determine the level and psychological and pedagogical conditions of their use in the modern educational process.

Analysis of recent research and publications. Issues of introduction of modern information means of training in the educational process were studied by I. Pidlasiy (Modern information technologies in training of specialists); E. Polat (Modern Information Technologies in the Education System); N. Basov (ICT - technologies in the formation of information culture of future specialists); M.Clarin (Teaching and assessment: ideal and reality); $\mathrm{V}$. Bezpalko (Using modern information technologies in education); O. Shiyan (Culture and application of information technologies);, J. Poplavskaya (Directions of introduction of new information technologies in the process of control and assessment of students' knowledge); V. Tinny (Information and Communication Technologies as a Means of Realization of Self-Educational Activities of Specialists), V. Shukshunov (Application of New Information Technologies in Pedagogy) and others. Didactic and methodological properties of mobile information tools were researched by N. Bondarenko (Mobile applications as a means of communication in the knowledge society: educational aspect); O. Pustovalova (Modern characteristics of the technology of mobile language learning as a pedagogical innovation); A. Avramenko (possibility of practical use of smartphones and tablets in foreign language classes at a higher education institution), etc. [1]. The analysis of the researches on the given problems leads to the conclusion that rational use of modern information mobile means in the educational process of higher education institutions will optimize the training of future specialists and will create more favorable psychological and pedagogical conditions for them.

Research presentation. In the framework of D. Miln's research, our society extends from the information age to the age of interaction, during which the role of digital content expands as such where people interact and what they interact for [2].

To sum up, "digital networks are evolving from data transmission in a purely transactional sense to facilitate social interaction" [3, p. 14]. Instead of simply delivering the document to the person's mailbox, the sender and recipient can use the network to conduct a real-time conference on the document. Second, students in the information age tend to have at least one portable computing device, such as a mobile phone, laptop, or even a portable gaming device. During this interaction, we observe the massive impact of these individual devices through enhanced work and play 
space that allow individual users to connect to portable devices for sharing and interaction, say, through the large screen interface, after entering the environment. Third, there is a growing focus on web technologies - this is to move today's students from graphical user interfaces to touch interfaces that provide a greater range of interaction modalities. Interactive smart boards, gesture-based games, digital pens, or even Han's cutting-edge multi-control interfaces allow for greater flexibility and accuracy in supporting human response. Fourth, more and more jobs require people to be drawn to group settings rather than individual indicators. Many learning environments have already begun to reflect this change by investing more in teamwork. Developing technologies are also beginning to be used by many people, although upgraded or adapted ones used by one person (interfaces) still prevail. The transition from the information age to the age of interaction is the basis for understanding learning environments as socio-contextual.

At such a changing age, students today are already different from students of the past in terms of how they have grown and used technology. Prensky M. [4] stresses on the uniqueness today's "digital indigenous" students. A series of empirical studies funded by the Pew Internet and American Life project [3] support the notion of modern students as digital natives.

Similarly, current educators point to some features of today's university students that should be considered when designing new training sites for them, including: a propensity for high-activity and large-scale research, both personal and digital, and simultaneously synthesized; technological skill and ubiquity, using mobile phones, digital cameras, MP3 players and wireless Internet to view, download and send messages; and several priorities, including school, work, sports, volunteerism that make time a precious commodity. In fact, Oblinger J. exemplifies the diverse and open spaces in which, and through which, today's students move through life as an incentive to change spaces in classrooms and campuses. Most researchers agree, but they also talk about such innovative spaces that are still rare and isolated.

Today, evidence suggests that today's student behavior patterns are changing, at least in part, with their rapidly expanding digital environment. Today, everything indicates that modern digital students think and process information differently from their predecessors - thinking in parallel and linear models and reading visual images that could be used to read a text.

Although digital technologies such as virtual reality tend to attract our attention, educators and researchers must balance the tendency to integrate with the latest pedagogical technologies; this is known to many and continues to be open about how people learn and improve their productivity. Involvement is a theoretical construction that has been disclosed in the literature as a prerequisite for active learning. Of course, new technologies such as those described above can give students of the Information Society and the Interaction Society the opportunity to gain increased and ongoing participation in learning.

The concept of interested learning has its roots in established and researched constructive foundations of learning, such as interest, effort, motivation, and time to task. Various authors have characterized interested learning as a high level of active student involvement developed in the learning plan. A students' understanding is formed if they take responsibility for their own learning, during which they actively develop thinking / learning strategies, constantly absorbs the formation and refinement of new ideas and through their speech exchanges with others. Active students interact with their environment and manipulate objects in that environment, observe the impact of their interventions, and build their own interpretations of the phenomena and results of manipulations, share these interpretations with others. Already, these descriptions offer connections to previously identified features of the Information Society and the Society for Interaction and New Technologies.

Some scientific groups have formulated indicators of active learning. They provided a set of eight learning-related indicators related to vision, objectives, assessment, model, learning context, grouping, role of teacher and student. First, teachers and students share a vision of active learning, in which students take responsibility for learning, are motivated to learn and vigorously learn, and are strategic in their learning. In the learning concerned, the tasks are credible, complex and multidisciplinary, and the assessments are based on reliable results, constant, numerous, varied and fair. These assessments are used by students and faculty to evaluate and develop learning in an interactive way. The model and context for learning are characterized by interactive learning modes with a focus on knowledge sharing. Students study together in heterogeneous and flexible groups with a teacher who acts as an informed guide and facilitator. Students change in a variety of roles, including interrogator, teacher, student, and producer.

Some researchers have offered interesting teaching basics that highlight the problem and the process, which is necessary for authentic learning. The framework includes six indicators: poorly structured, multi-disciplinary issues; the degree of ownership of learning goals, processes and research strategies (eg problem deconstruction); student collaboration with all, flexible roles and accountability; self-control and evaluation of the learning process; use of teachers and experts to provide tools, techniques and support; and real tools to open communication and exchange of experience between students, faculty and experts. Foreign scientists who have researched the issues of the modern educational process in higher education institutions are focusing their attention, within the stated problems, that from a sufficiently deep overview of modern ideas in the teaching of constructivism, that includes cognition, authenticity in learning, self-regulated learning. It should be noted that the index of cooperation and accountability of students is empirically supported [3; 4].

Another point of view in learning is in Wang Kang's research, who grouped indicators of participation in three areas: cognitive, emotional and social. In a cognitive environment, learning differs from the construction and emergence of knowledge, as well as student self-regulation. In the emotional sphere, interested learning is indicated by students who feel safer and more confident. In the social sphere, there are indicators of information / resource sharing and group cohesion and acceptance of one another in the context of cooperation. Each of these domains and their associated metrics are considered in the light of both training and assessment. This database provides a simple guide to the important elements in the learning environment for creating high engagement. However, as Kang V. notes, it should be researched [5].

In any case, the current level of development of technical means has led to the emergence of new approaches in the preparation of future qualified competitive specialists. It is relevant and necessary today to organize the educational process on the basis of specialized applications for mobile devices. The methodological problem of using mobile applications in the educational process is the compilation of a typology of tasks, special formats for all stages of courses based on specialized applications - from the introduction and consolidation of training material and development of skills and their intermediate control to the formation of perceptual and productive activities, socio-cultural competence 
and final control. In addition, the organization of monitoring, analysis and evaluation of the quality of training using mobile technologies at all stages of the learning process is quite a difficult issue [1, P.201].

The term "mobile learning" appeared in English-language pedagogical literature more than ten years ago and has recently become increasingly used in Ukraine. There is no doubt that modern training in mobile information technology depends on the proliferation of mobile communications, the popularity of smartphones and tablets, the emergence of a large number of training programs and applications, as well as new technologies, such as gestural interface, which empower the process teaching. The definition of "mobile" characterizes first and foremost two main components of the pedagogical process: access to learning tools and forms of implementation of educational interaction. Today, students can have instant access to study materials and programs, teaching resources, complete assignments, communicate with the teacher at any time, anywhere, thus shaping sociocultural and intercultural competences.

Educational mobile applications are conditionally divided into: mobile applications intended for self-study of the discipline, which can be used as additional material in the classroom and beyond for the development of different skills; mobile curriculum supplements, which are textbook and course additions, appropriate and convenient to use with essential classroom or nonclassroom materials; mobile applications intended for the distance (mobile) form of education, containing the main teaching material with tests, a system of checks and references, feedback from the teacher [1, P.202].

Also in the educational process use e-learning, mobile learning (m-learning), blended learning. These technologies allow for lifelong learning. The term "e-learning" means a learning process that uses interactive electronic means of information delivery, electronic media, corporate Internet networks. In addition to electronic libraries, courses, tools for developing the content of the educational process, the system of management of the educational process, independent work of students, e-learning technologies are used, which are also applied in virtual audiences and educational institutions. The development of e-learning is putting forward a new promising model of learning, built on the use of the latest multimedia technologies, the Internet, with the aim of improving the quality of learning, facilitating access to resources, services, and sharing and collaborating at a distance [6].

The goals of using e-learning are:

- work independently with electronic materials using a computer, mobile phone, etc.;

- obtaining consultations, holding meetings, evaluating a remote expert (teacher), the possibility of remote interaction;

- creating a distributed community of users who engage in virtual learning activities;

- timely continuous delivery of e-learning materials;

- standardization and certification of e-learning materials, technologies, distance learning;

- formation and enhancement of information culture of all participants of the educational process;

- mastering, promoting and transferring innovative pedagogical technologies, improving the effectiveness of teachers' activity;

- opportunities to develop educational Web-resources;

- opportunities at any time, from any place to acquire modern knowledge;

- accessibility of education to all comers.

The other technology is a mobile learning (m-learning) a transfer of knowledge to a mobile device using WAP or GPRS technologies that makes learning flexible, accessible and personalized. The m-learning system extends the possibilities of training, obtaining additional educational services, necessary consultations, answering the questions of independent planning and realization of training on its own trajectory, etc. Possibilities of using mobile devices in the educational process in higher education institutions:

- mobility of participants in the educational process;

- widening the boundaries of the educational process;

- distribution and exchange of materials with the help of modern wireless technologies;

- promotion of better learning of educational material.

The modern educational process uses blended learning, which is a combination of traditional learning and e-learning. The advantages of blended learning are:

- acquiring knowledge as a result of personal communication between students and teachers:

- taking into account the individual features of human perception of information

- eliminating the likelihood of loss of information due to the fact that the electronic course allows you to return to any part of the material being studied;

- creation of a unified knowledge base;

- assimilation of new knowledge, consolidation of previously obtained knowledge;

- variety of forms of training organization;

- flexibility of the program, possibility of choosing a module of training;

- stimulating the development of self-study skills and information seeking;

- the possibility of prompt feedback from all participants of the educational process;

- convenient pace, time and place for training;

- the possibility of combining learning with work;

- the possibility of taking training to a new level [6].

Therefore, the use of mobile devices will significantly increase the efficiency of the educational process in higher education institutions, namely: by providing access to teaching and reference resources, organizing teacher interaction with students in real time, organizing distance learning, testing opportunities, surveys, questioning, use of other tools in the educational process. This determines the prospects for further research, since the use of modern information and communication and mobile technologies is preferred in the modern educational process in institutions of higher education.

Conclusions. All approaches are quite evident for active learning. Student responsibility for learning is manifested in a variety of ways, including the setting of learning goals, the joint design and representation of knowledge, the acceptance of various roles and tasks, participation in selfmonitoring and assessment. Second, flexible group collaboration is also emphasized. Third, the use of diverse and relevant human and non-human resources (teachers, experts, tools, processes, methods, etc.) to support learning is consistent in all cases.

According to the analysis of scientific and pedagogical research, it became clear that the student personality is a common indicator of the learning involved, and given that mobile learning devices can provide individuality through unique profiles, this category of technology can be a proper choice of learning environment aimed at enhancing individuality into learning. Mobile devices are certainly in line with how things are happening around the world and the web, even if those devices have been used for personal purposes only. A critical aspect of such a strategy is that the mobile device has not simply integrated into the educational and higher education institutions or fallen into the hands of its user, as has been done, for example, with recent initiatives 
on computers and laptops. On the contrary, individual profiles (such as electronic goal setting, monitoring, reporting, and adjustments) must be intentionally designed into the device and involved in the educational process in general and higher education institutions in particular.

References

1. Bruchal JB, Bilyk OO Essential characteristics of the technology of mobile learning of foreign language as a pedagogical innovation // Scientific journal "Young scientist" № 6 (46) June, 2017, p.201.

2 Milne D. An Empirical Definition of Clinical Supervision // British Journal of Clinical Psychology. - 2007.- №46.- P.437-447.
3. Lenhart A., Madden M., \& Hitlin, P. (2005, July 27). Teens and technology: Youth are leading the transition to a fully wired and mobile nation. Pew / Internet \& American Life Project. March 16, 2007, access link http://www.pewinternet.org/pdfs/PIP_Teens_Tech_July 2005. pdf.

4. Prensky Marc. "Digital Natives, Digital Immigrants, Part II: Do They Really Think Differently?" // Horizon (NCB University Press) / -2001 / -№6.

5. Richey RC, Klein JD \& Nelson W.) Studies in Instructional Design and Development.- 2004 Access link: https: //www.google.co.id/? Gws_rd = cr, ssl $\&$ ei $=$ vjMJWfnBJcPavASyv7-4Bw \# $q=$ Seals + and + Richey + developmental + research.

6. Access mode: http://www.kpi.kharkov.ua/archive

Надійшла до редколегії 16.08.19

О. Поляк, канд.пед. наук, доц.

Київський національний університет імені Тараса Шевченка, Київ, Україна

\section{СУЧАСНІ ІНФОРМАЦІЙНІ МОБІЛЬНІ ЗАСОБИ НАВЧАННЯ В ЗАКЛАДАХ ВИЩОЇ ОСВІТИ}

Стаття присвячена сучасним інформаційним засобам навчання як способу оптимізації процесу підготовки майбутніх фахівців.

Наголошено на значущості області технологічних інновацій та області теорії навчання в рамках застосування різноманітних технологій для навчання та викладання.

Визначено, що моделі поведінки сучасних студентів змінюються, щодо їхнього рідного середовища цифрових технологій, які стрімко розповсюджуються. Сучасні цифрові студенти обмірковують та обробляють інформацію принципово по-іншому, на відміну від своїх попередників - мислячи паралельними та лінійними моделями та читаючи візуальні зображенння, за допомогою яких можна було б читати текст.

Наголошено на тому, що нові технології, як ті, що описані в статті, можуть надати студентам інформаційного суспільства і суспільства взаємодії можливість отримувати підвищену і постійну участь у навчанні.

Активні студенти взаємодіють зі своїм середовищем і маніпулюють об'єктами в цьому середовищі, спостерігають за впливом їх втручань і будують власні тлумачення явищ та результатів маніпуляцій, поділяють ці інтерпретації з іншими. Ці описи пропонують підключення до раніше виявлених рис інформаційного суспільства і суспільства взаємодії та нових технологій.

Проаналізовано різні підходи забезпечення сучасного активного навчання в закладах вищої освіти. Резюмовано про те, мобільні навчальні пристрої можуть забезпечувати індивідуальність через унікальні профілі, ця категорія технологій може стати належним вибором навчального середовища, спрямованого на посилення індивідуальної спрямованності в навчання. Мобільні пристрої мають узгоджуватись з тим, як відбуваються події в світі та в Інтернеті, навіть якщо ці пристрої були використані лише для досягнення особистих цілей. Закцентовано, що критичний аспект такої стратегії полягає в тому, що мобільний пристрій не просто інтегрувався є навчально-виховне середовище та у заклади вищої освіти або впав у руки його користувача, як це було зроблено, наприклад, з нещодавніми ініціативами щодо комп'ютерів та ноутбуків. Навпаки, індивідуальні профілі повинні бути навмисне спроектовані в пристрій $і$ задіяні в освітньому процесі в закладах освіти взагалі та в закладах вищої освіти зокрема.

Ключові слова: мобільна інформаційна технологія, мобільні пристрої, електронне навчання, мобільне навчання, змішане навчання, активне навчання.

UDC 378.147.34

Y. Spitsyn, Doctor of Sciences (Pedagogics), Professor, V. Zaitseva, master's student Taras Shevchenko National University of Kyiv, Kyiv, Ukraine

\section{ACADEMIC INTEGRITY OF STUDENTS: PEDAGOGICAL CONDITIONS OF ITS CONTROL}

In the article, the problem of academic integrity of students of higher education institutions is considered and the main pedagogical conditions for reduction of manifestations of academic insanity are offered on the basis of three interrelated psychological and pedagogical components: motivational, normative and cultural value.

Keywords: academic integrity, manifestations of academic integrity, academic responsibility.

Formulation of the problem. In the context of active reform of the higher education system in Ukraine, actual and problem issues are raising its quality. As stated in the Law of Ukraine "On Education", one of the important components of the internal quality assurance system is the system and mechanisms for ensuring academic integrity [6]. In turn, academic integrity concerns not only the quality of education - it significantly affects those citizens who are educating the higher education system in the country, which values are laid down while studying at the university. Our pedagogical observations, interviews with students and teachers indicate that the majority of the subjects of the educational process recognize that manifestations of academic dishonesty take place, but not all of them are ready to recognize their systemic problems in higher education institutions. Thus formed the so-called "vicious circle" fraud and corruption of education - the negative effects of social inequality (results are not to reach by the best but by the fastest) - low level of experts are braking economic and cultural development of society.

It is worth noting that the concept of academic integrity for Ukrainian realities is rather new, although in the foreign scientific community issues of academic integrity have been under way for quite some time.

The International Center for Academic Integrity at the Rotterdam Institute of Ethics at Clemons University in South Carolina has developed a document entitled "Fundamental Values of Integrity", which states that academic integrity is a commitment to six fundamental values: honesty, trust, justice, respect, responsibility and courage [11]. The Law of Ukraine "On Education" states that " An Academic integrity is a set of ethical principles and statutory rules that should guide the participants in the educational process while teaching, educatingand conducting scientific (creative) activities in order to ensure trust in the results of learning and I or scientific (creative) achievements. Adherence to the academic integrity of the applicants of education implies:

- independent performance of educational tasks, tasks of current and final control of learning outcomes;

- references to sources information in case of using ideas, developments, statements, information;

- observance of the norms of the legislation on the copyright and related rights;

๔ Spitsyn Y., Zaitseva V., 2019 